\title{
4
}

\section{MASCULINITIES AND MUTED \\ GENDER IN BALI AND KALIMANTAN}

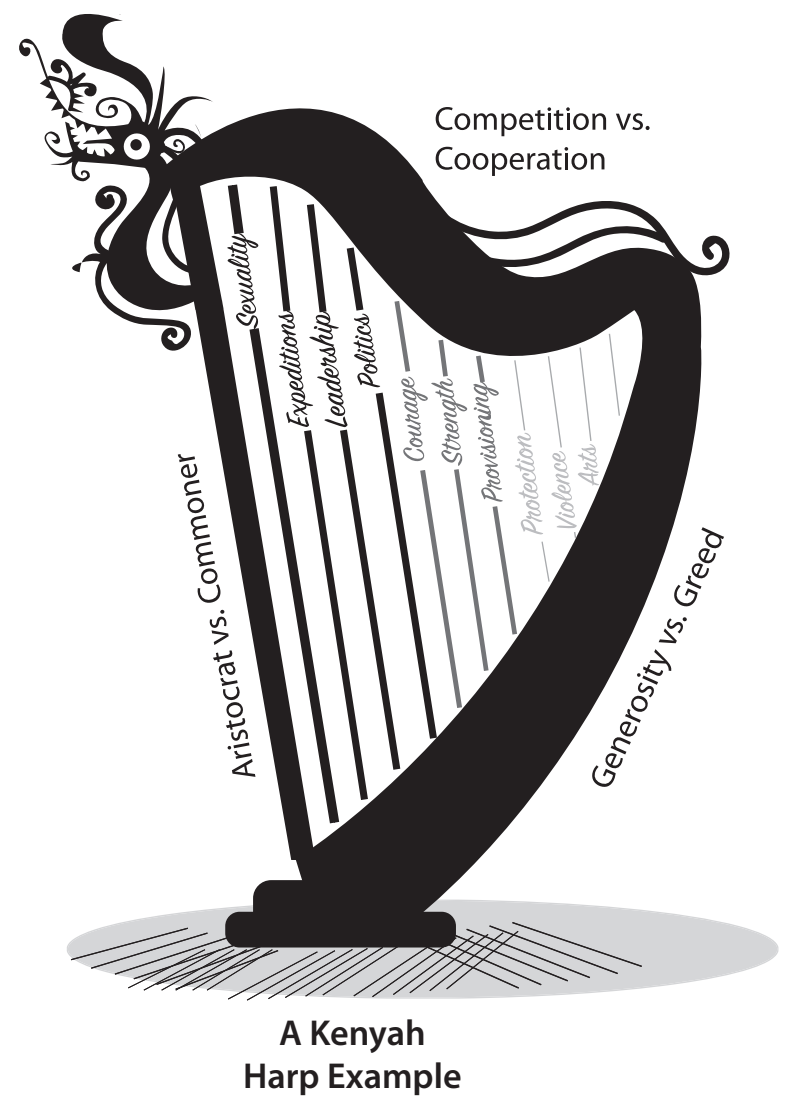




\section{Introduction and reflections}

I arrived in Indonesia for the first time in June 1978, 33 years old, alone and without friends or language capability. I did have the names of some people that friends in Hawaii thought would help me. On arrival, in the middle of the night, I remember my excitement tinged with a bit of anxiety as the taxi driver and I struggled to communicate and find my friend's house (no Google Maps, of course) in the sprawling Jakarta metropolis. I knew only that it was 'near the prison'.

My first surprise was the care these people, including men, took of me. Cars drive on the left side of the street in Indonesia, and I had difficulty at first remembering to look the proper direction as I moved out into the chaos of Jakarta's traffic. One young man I'd just met at Jakarta's Population and Family Planning Bureau (BKKBN, Badan Kependudukan dan Keluarga Berencana) held my hand as we crossed streets, recognizing my incompetence and saving me from certain death. Another stranger took me in hand on my trip to Yogyakarta, helping me find a place to stay and the address of a mask maker who would lead me to the young Nancy Peluso, already long resident in Indonesia. I was intrigued by the kindness I was shown by men who didn't know me, and without obvious ulterior motives.

My first visit of any length was in Bali, an interlude in which I learned rudimentary Indonesian and began to acclimate to the country-in its late 1970s state. The lack of concerns about privacy, people's willingness to share their lives, their ideas, their way of life, all were a delight for an anthropologist tired from the suspicion and prickliness of Bushler Bay's residents. Bali, as part of 'inner' Indonesia, in Geertz (1963) terms, was tightly integrated with national and even international policy, densely populated, nationally recognized as 'civilized', hierarchical and Hindu-all unlike the Kenyah situation discussed later in this chapter. I would encounter some of these qualities again, in Sitiung (Chapter 5).

The Bali of 1979 was characterized by different axes of power than today's Indonesia. The government was super-centralized, with power clearly in the hands of President Soeharto and his cronies. Java and Bali were differentiated very clearly from the 'Outer Islands' (Chapter 5). There was little or no awareness, to my knowledge, of gender as an issue, but family planning was one of the central government's primary concerns. And many governmental policies included sexist assumptions about gender (discussed by Elmhirst 2011, for the transmigration programme, and in Chapter 5) - men as heads of households, women as homemakers, men as land owners, breadwinners, politicians, etc. The intersection of gender with other social categorization is obvious, with caste, educational level, race, nationality and occupation all relevant in the discussion in this chapter (indeed, throughout this book).

I introduce this urban, only peripherally forested place, for three reasons. The first is to provide continuity in my unfolding understanding of masculinities . . as I moved from the very polarized gender world of the US to Indonesia, where 
many groups did not so clearly differentiate. ${ }^{1}$ The second is to take advantage of the opportunity to briefly highlight, yet again, the divergences in masculinities, even within one country. And the third is to introduce briefly international masculinities - through donor actions, competition among scientists and institutions and different scientific preferences-more fully explored in Chapter 6 . The willingness to accept the views of donors and outside experts, and act on their suggestions, was much higher in the 1970s than it is today. Again, I set the stage by explaining a bit about the biophysical environment.

\section{Bali: my introduction to Indonesia ${ }^{2}$}

In Bali I lived an urban life, working among elites. The area around Denpasar, a plain, had more than 500 people per square kilometre, yet still the island was considered a tourist's paradise. ${ }^{3}$ Rainfall in the city was between 1500 and 2000 $\mathrm{mm} /$ year, higher in other areas of Bali. Not devoid of tropical rainforest, the nearest was north of the city: moist deciduous forest (the most common forest type on Bali), with some areas of evergreen and semi-evergreen rainforest further north, most above $500 \mathrm{~m}$ elevation. When Whitten, Soeriaatmadja, and Afiff's (1996) book was published, only 18\% of Bali was forested (a bit over $100,000 \mathrm{ha}$ ), though there was at that time a probably unrealistic plan to expand that to $31 \%$. Manilkara kauki was the most important indigenous species found in lowland areas (short, stocky and used for woodcarving); 5000 ha of this species along with teak and other timber species were planted by the Indonesian government in the early 1960s. Far more ubiquitous in the landscape were the beautiful rice terraces that lined hillsides.

Entranced by the beauty of the island, I was also immediately struck by the deep dark pools of men's (and women's) eyes, which seemed-in my youthful naiveté-to allow me to see directly into their souls. There was an openness, a kind of social trust and caring, that were new to me and in which I happily basked for the two months I stayed there. Social interaction felt like being bathed in a pool of warm water; people were gentle and helpful, with no hint of the suspicion I'd lived with for my three years in Bushler Bay or my nearly seven years in Turkey. It was a soothing place. ${ }^{4}$ But my understandings of masculinity there are far more superficial than in the places where I stayed longer.

I became very close to my hostess, a wealthy and beautiful woman about my age. Her husband, a physician, had been in graduate school with me and had graciously invited me to stay in his 'empty' house with his wife. ${ }^{5}$ I was also connected with the highest level officials, almost all men, within Bali's very successful family planning programme; with consultants who came through, many from Australia; with anthropologists briefly in town from the field; and with officials and professors at Udayana University. I quickly encountered the relevance, and different manifestations, of several familiar harp strings.

Sexuality was a key concern. My hostess had considerable interest in her own, her friends' and her family's (and my own) sexuality. Her husband, away in Hawaii, had been so concerned to ensure her fidelity that he'd installed his 
mother in his office, instructed three of his female relatives to sleep outside her bedroom door every night, hired his friends to work in the hotel where she worked and removed her IUD_all as preventive measures.

Although extra- and pre-marital sex were disapproved and the subject of much discussion, both were considered common. Men flirted with me incessantly, though never harassed. My hostess had many questions about American sexuality, and the Balinese loved discussing extra-marital affairs, some with serious consequences for the participants' careers. In one then-recent case, two married doctors had an affair, which became widely known. They both left Bali, going to different cities on Java, both their licences to practise in Bali revoked for two years. When I asked why that had been necessary, an anthropologist experienced in Bali told me, "The Balinese say they [the doctors] couldn't control themselves, and that you can't trust doctors who can't control themselves" (notes, 4 August 1979). In both these examples, sexuality and control were closely linked. My hostess told me,

Balinese believe that men are at their strongest (kuat) for sex when they are about 40 and that they begin to look at younger women when their wives are about 40 . Women are believed to go downhill sexually after that.

(notes, 20 July 1979)

The most dramatic surprise related to sexuality and reproduction came toward the end of my stay, by which time I'd learned a little Indonesian. I was invited by the Dean of Udayana University's Medical School, with which I was loosely affiliated, to attend a vasectomy clinic in Karangasem to the east (notes, 11 August 1979). Some distance from Denpasar, we came to a small, simple clinic where 42 men were seated in rows on benches on a veranda. They looked friendly, comfortable and at ease. I was surprised to learn that they were waiting to have vasectomies. I kept imagining the likely reaction should a man from Bushler Bay be invited to have his vasectomy so publicly. But more surprises were to come. Inside the building, there were five operating tables, on each of which lay a man with a green cloth covering all of his body, save his head and his genitals. My small group of medical professionals, all men, engaged the patients in friendly conversation. The latter responded with apparent ease and no hint of embarrassment, smiling with their open friendly eyes at me as well. The next surprise was the appearance of a television crew, which proceeded to interview the men and film their vasectomy operations. These images were shown on television that evening for all to see. There was obviously a very different attitude about vasectomies (and masculinity) in Bali than I'd encountered in Bushler Bay or with my own grandfather. Men's enthusiasm to undergo this procedure may have been linked to its perceived modernity, to 'things western' and national priorities at that time. ${ }^{6}$

Family planning of all kinds was organized very publicly in Bali. There was a strong push from Indonesia's President Soeharto encouraging family planning throughout the country - so strong that some international actors criticized the 
government for forcing people to practise birth control. ${ }^{7}$ The vasectomy clinic was attended by high-level government officials from the district, the military, the police, the Health Ministry and BKKBN. The BKKBN director had a direct mandate from the president, and thus was able, unlike most government leaders, to involve other ministries in his efforts.

The Balinese had cleverly incorporated family planning into their Banjar system. Each neighbourhood had a Banjar composed of local men, who met regularly to organize and monitor community affairs. Unlike in Bushler Bay, politics was primarily in the hands of men. To this task was added the responsibility of ensuring compliance with the family planning programme. Spray painted on the front of each house was the birth control method that family used. I detected no hint that any kind of family planning was private or embarrassing in any way; nor did it seem associated with masculinity (or the lack thereof). Discussion and approval of family planning were very common among both men and women, though its distribution was in the hands of men.

As with Bushler Bay's Public Employees, hierarchy was important in Bali, but its manifestation differed greatly. The hierarchies of the various agencies and departments were further complicated by the existence of a separate and explicit caste system; men were expected to marry within their own or a lower caste. Dr. Ngurah Bagus, an Udayana University anthropologist, noted that the

lower castes have been fighting the caste system a lot. There used to be restrictions on marriage, speech and eating together. Now only on ceremonial occasions is there separate eating. And marriage is becoming more common between castes, though families are still not happy. It particularly messes things up on ceremonial occasions, if a woman marries beneath herself.

(notes, 13 August 1979)

My hostess had done just that and had had to wait eight years before she and her husband were able to marry, perhaps because of the caste difference.

Language, as Drs. Bagus notes, also remained a problem, as there are refined (halus) and coarse (kasar) forms of the Balinese language:

In order to avoid the confusion of when to use halus and kasar Balinese, lower caste people use Bahasa Indonesia. He said it's no problem for the upper castes, only for highly placed lower castes. He said sudra, the word I'd learned for lower castes, is an insult; we must use jaba or orang kebanyakan ['most people'].

(notes, 13 August 1979)

These national hierarchies were compounded among these elites by relations between Indonesia and potential donors-a topic I explore in some detail, in anticipation of Chapter 6. In 1979, Indonesia had only recently emerged from three centuries of Dutch colonial rule. Many of those in power retained a sense of 
the superiority of all things western and white, and formal education. Although the funds available from external donors were very much desired and welcomed on their own, there remained also a sense of subservience and extreme respect granted to people from the US and western Europe. ${ }^{8}$

Having come from the University of Hawaii to complete my master's in public health, I was affiliated with an impressive and well-respected American professor, active both within our university and within USAID, whom I'll call Dr. Q. His expectation of control in his relations with the Balinese was clear:

Dr. Q . . is squiring around some hotshot from AID. I asked about the nutrition mess, and he said it was all ok, it had just stopped progressing while he was in the US. He said at one point he got so mad at Pak A [a BKKBN official] he told him he was going to take back his diploma. [Another BKKBN official] told Dr. Q that the workshop will have to be postponed because AID hasn't paid the money yet. But Dr. Q's gonna bring [an American doctor] as planned and pretend he was supposed to be in on the planning.

(notes, 25 July 1979)

At the same time, Dr. Q showed his commitment to a caring or protective role, both with the Balinese and with me. In one case, he seemed to opt for my benefit over that of his hosts: he insisted that I be included in a planned budget as a foreign, rather than a local, consultant. I would thereby get much more money than the Balinese counterpart consultants. But his reasoning showed his real concern for project success: if I weren't available to do it (a distinct possibility), that larger sum could be shifted to [more] Balinese consultants.

There was also evidence among the Balinese BKKBN bureaucratic men of a strong preference for mathematical and experimental approaches to research (as in the US). B [a junior BKKBN official] and I

met to go over the methodology section I'd written. He was not at all shy to explain what he thought should be in the proposal. He prefers mathematics to reading or memorizing. Teaches nutrition and statistics.

(notes, 9 August 1979)

Drs. C [anthropologist] says he himself

always attacks the people at Kedoktoran [Ministry of Health] and Public Health because they don't make use of the knowledge of other disciplines. He said, with sex education, we [at Udayana University] have an Education Department, but they don't use it. They're too narrow minded. They think they're better than us. He was as vehement as I've seen Balinese get. It was a sentiment I recognized well [in interactions between qualitative and quantitative researchers]. 
Hierarchy strikes me as a stronger social structural principle in Bali than gender differentiation. ${ }^{9}$ From an international perspective, I was, for instance, more fully and readily included in the work of BKKBN than an equally qualified Australian man, ${ }^{10}$ who encountered one roadblock after another. I thought my access derived from my affiliation with Dr. Q, who had funds and knowledge he was trying his best to share. The fascination many Indonesians had with white women could also have played a role. The neglected Australian (L) recounted his experience to me:

He . . . met Dr. Q when he'd been in Indonesia for three days. Was introduced by someone who was urging Dr. Q to use this demographer's expertise. L said he felt like he was caught in a power play, and that Dr. Q had felt $\mathrm{L}$ was messing around in his backyard. Sounded like a quite unpleasant interchange, and he said, "neither of us has gone out of our way to mend fences". He thought there was a rivalry between the Hawaii mafia and the ANU crowd of demographers.

(notes, 14 August 1979)

The high-status men with whom I was primarily working took their leadership - another common masculine harp string-responsibilities seriously. The head of BKKBN in Bali spoke at length about his leadership philosophy and experience. He

expressed a philosophy of working behind the scenes, getting people's cooperation, stepping out of the limelight (e.g., writing the speech the governor gives, arranging the [vasectomy] camp that's officially the Bupati's [district leader's] shindig). He believes in delegating so that the thing is theirs, not his. He also believes in making use of the powers that be.

His organization is outside the regular bureaucratic structure, and he is therefore, with the active help of the [central] Government, able to coordinate the Ministry of Education, the Ministry of Information and the Ministry of Health. He attributes a lot of his success to his utilization of the powers that be to back his programs. He also recognizes the importance of making the program belong to the people it serves. Both these concepts came through again and again. He said he speaks halus to villagers. He also spoke Balinese to them, to be closer to them, he said. Both he and the Bupati asked the villagers if they had been pressured or if this [having a vasectomy] was of their own free will (for my benefit? Or to show each other?). I noticed that the Bupati gently helped a man off the operating table in a caring way. He also was the first person to offer blood. Both reiterated the necessity for leaders to be the pioneers and were happy when a kelian [banjar leader] had been the first vasectomy acceptor, though neither of them had had a vasectomy. The Bupati said 
his wife was one of the first tubectomies, and [the BKKBN head] said his wife didn't want him to.

(notes, 11 August 1979)

To sum up, some of the key concepts observed among men in Bali included sexuality, control, leadership, competitiveness and comfort with hierarchy - this latter more complex and pervasive than that seen among Public Employees in Bushler Bay. Among the internationally involved, again control and competitiveness were evident, as was a preference for math and science, the quantitative and experimental over qualitative observational research methods. There was also a comfort among these men with issues of sexuality, at least as pertained to family planning, that would not recur among my colleagues in the natural resource fields discussed in Chapter 6.

All in all, this detour in Bali began my process of moving out of an American polarized view of gender to a much more flexible one than I had ever encountered before. It introduced me to Indonesian science, governmental bureaucracy and donor relations, and primed me for the new and unearned respect I would be given because of my colour, comparative wealth ${ }^{11}$ and academic degrees. These latter overshadowed my gender in these contexts.

\section{Masculinity among the Uma' Jalan Kenyah Dayaks ${ }^{12}$}

Bali had been a brief introduction to one partial version of masculinity in Indonesia. Long-term research took me to East Kalimantan in September 1979. I have no words to convey my utter delight at the prospect of going deep into a tropical forested world, a world totally new to me. I begin this journey with a description of the biophysical world of the Kenyah in the 1970s and ' 80 s.

\section{Introduction to Long Segar, East Kalimantan}

Long Segar is in the middle of East Kalimantan, situated along the Telen River (see Figure 4.1). An unusually forest-rich environment at that time, ${ }^{13}$ it was surrounded most closely by a patchwork of upland rice fields, early and late secondary forest. As the distance from the village increased, so did the amount of old growth forest. Population density in the area was estimated at $2 / \mathrm{km}^{2}$ (Directorate General of Forest Utilization 1989). Dipterocarps, the dominant commercial species, could reach 45-60 m or occasionally taller and sometimes comprised as much as $10 \%$ of all trees and $80 \%$ of all emergents.

The combination of very high stocking of trees with huge boles, commonly $20 \mathrm{~m}$ long or more, and of relatively light weight, has encouraged extensive exploitation of dipterocarp forests throughout Southeast Asia.

(MacKinnon et al. 1996, p. 177) 


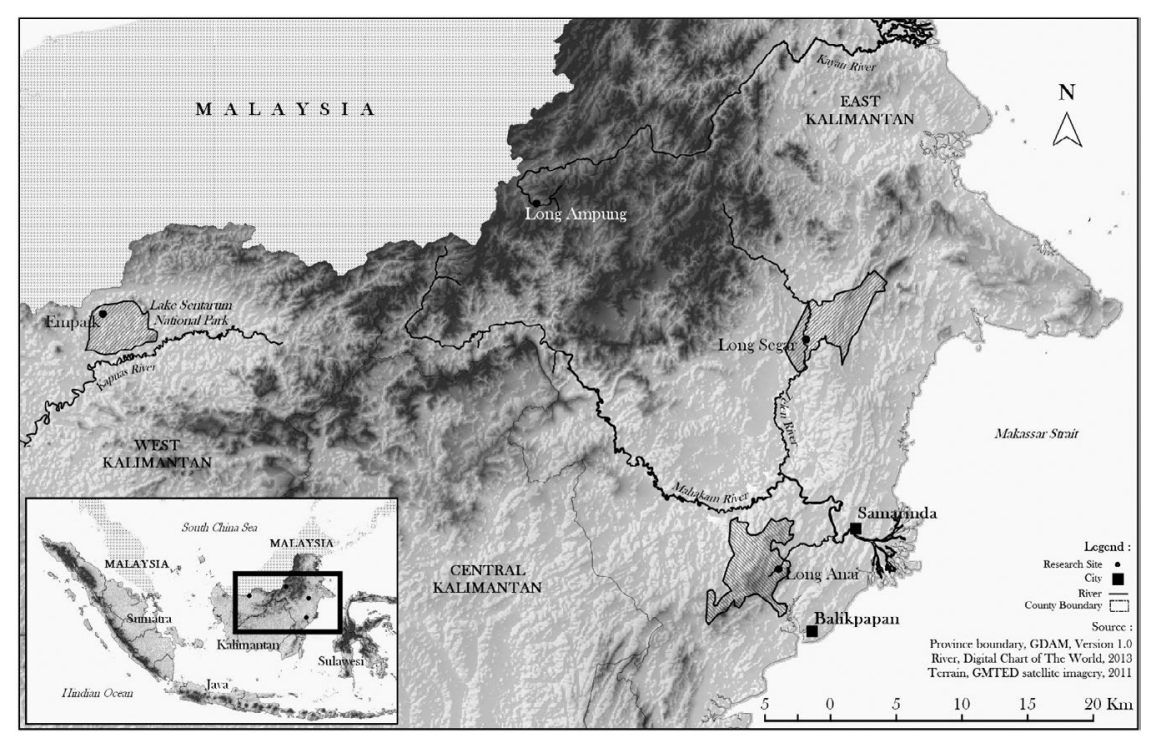

FIGURE 4.1 Map of East Kalimantan research sites.

The Long Segar area was a perfect example. Timber companies were operating all around the community, which had been declared part of Indonesia's Forest Estate. The biggest concession (in which Long Segar itself was located) was managed by the American Georgia Pacific Company (turned over to PT Kiani Lestari after the fires of 1982-1983).

Although the very centralized Ministry of Forestry officially managed the area from Jakarta, day-to-day management was in the hands of the American company, with only an occasional visit from forestry officials. This concession was categorized as production forest and was logged primarily for its valuable dipterocarps ( ten trees/ha). Although the US Foreign Corrupt Practices Act had already been passed (1977), there was a widespread belief that all the timber companies in the area ${ }^{14}$ bribed officials and followed governmental regulations only along good roads that the companies maintained close to base camps. In these easily accessible forest areas, prescribed management (e.g., cutting guidelines, annual allowable cut limits, replanting, etc.) was followed. Visiting officials were not usually anxious to take long, hot, bumpy rides over muddy or dusty logging roads into more distant areas. ${ }^{15}$ The companies were able to do as they chose-what was most profitable-in the remainder of the concessions. They were also able, in effect, to bribe local leaders to accept whatever management practices the companies chose, framed as fulfilling their legal obligations to contribute to the well-being of local communities (see Chapter 7, for similar narratives among oil palm companies). 
The main dipterocarps included Dipterocarpus, Dryobalanops and Shorea (emergents) and Hopea and Vatica, smaller trees. The legumes included Dialium, Koompassia and Sindora (all emergents). One particularly interesting species was the magnificent tanyit (Koompassia excelsa), with its white bark and high, spreading canopy (one example in nearby Sarawak reached $83.82 \mathrm{~m}$ ) - the tallest broadleaf rainforest tree in the world and home to honeybees.

Another key species in the area was beli'en (Eusideroxylon zwageri), or ironwood, used in much construction locally (see Colfer, Peluso, and Chin 1997, for lists of various forest products - timber, fibres, foods and medicines - used by the Kenyah). MacKinnon and MacKinnon (1986, quoted in MacKinnon et al. 1996) note that by 1986, 60\% of the original area of ironwood forest had been lost, as had a third of lowland dipterocarp forests in Kalimantan generally (p. 398). Another important species used by the Kenyah was rattan (especially Daimonorops spp., Calamus javensis, C. caesius, C. trachycoleus, Korthalsia echinometra, K. rigida and Plectocomiopsis geminiflora), though used more commercially by the Kutai community of neighbouring Kernyanyan (Colfer, Peluso, and Chin 1997).

In 1981, log production in East Kalimantan was 2,856,560m³.

In 1978, this province with less than 1\% of Indonesia's population, produced nearly $25 \%$ of the country's total export earnings, mainly from timber and petroleum products.

(McKinnon et al. 1996, p. 401)

This forest, in 1979 well protected by the humidity and extent of old growth forest, began to suffer from devastating forest fires whenever El Niños of any severity occurred (e.g., 1982-1983, 1997). Although there was a serious El Niño in 1972-1973, which caused great difficulties for the Kenyah, the main problem then was a failed rice crop, rather than a totally burned and devastated landscape (Colfer and Dudley 1993).

I initially went to Long Segar, accompanied by a senior forestry student from Mulawarman University (Albar Azier), prepared to conduct a conventional ethnographic study. I immersed myself in local life, living with the village headman's family of 14, from October 1979 to August 1980. In February, I was joined by my ten-year-old daughter and soon-to-be-ex-husband (the latter staying until May). I spent May 1980 in Long Ampung, the village from which Long Segar residents had moved between 1963 and 1972.

Soon after my arrival, I was struck by the degree to which the differentiation between men and women was muted, ${ }^{16}$ vis-à-vis the situation in the rural US. I had just come from a community where men and women were seen as polar opposites (as Newton 1977 found in Hawaii); in Long Segar, they were seen as quite similar. We might say that the Long Segar harp of masculinity is smaller than that of Bushler Bay, or perhaps its sounds have been dampened to softer tones. Or perhaps the harp is simply one of humanity rather than of masculinity per se, with men plucking somewhat different strings and clusters, creating 
somewhat different songs. Mashman and Nayoi (2015) reflect another common academic view of Indonesian gender relations (at least outside Java and Bali): "Complementarity seems to be the more relevant mode of analysis, as opposed to asymmetry and inequality" (p. 960). ${ }^{17}$

In 1980, I conducted a cognitive mapping study (called 'Galileo'), designed to quantify people's perceptions of men, women and natural resource concepts. ${ }^{18}$ The resulting 'map' and matrices showed the average cognitive 'distances' people attributed to pairs of concepts in a multidimensional space. With ten points being the 'length' of the cognitive measuring tape, respondents assessed men and women, on average, to be two points apart — providing some quantification of the widely recognized common humanity of Kenyah women and men. Another interesting concept was good. The women-good link was assessed, on average, as 1.8 (along with rice field-good; only work, at 1.4 had a closer link to good); the men-good link was 2.2. The greatest distance mentioned in this adult dataset was between trade and child, 7.4; the smallest pairs were woman-child and cottage industr $\gamma^{19}$-work (see Figure 4.2 and Table 4.1). .

Uma' Jalan Kenyah had lived for about a century in Long Ampung, in the remote interior of Borneo, bordering Malaysia (see Figure 4.1). In 1963, a small Protestant segment of the community had moved to the somewhat more accessible

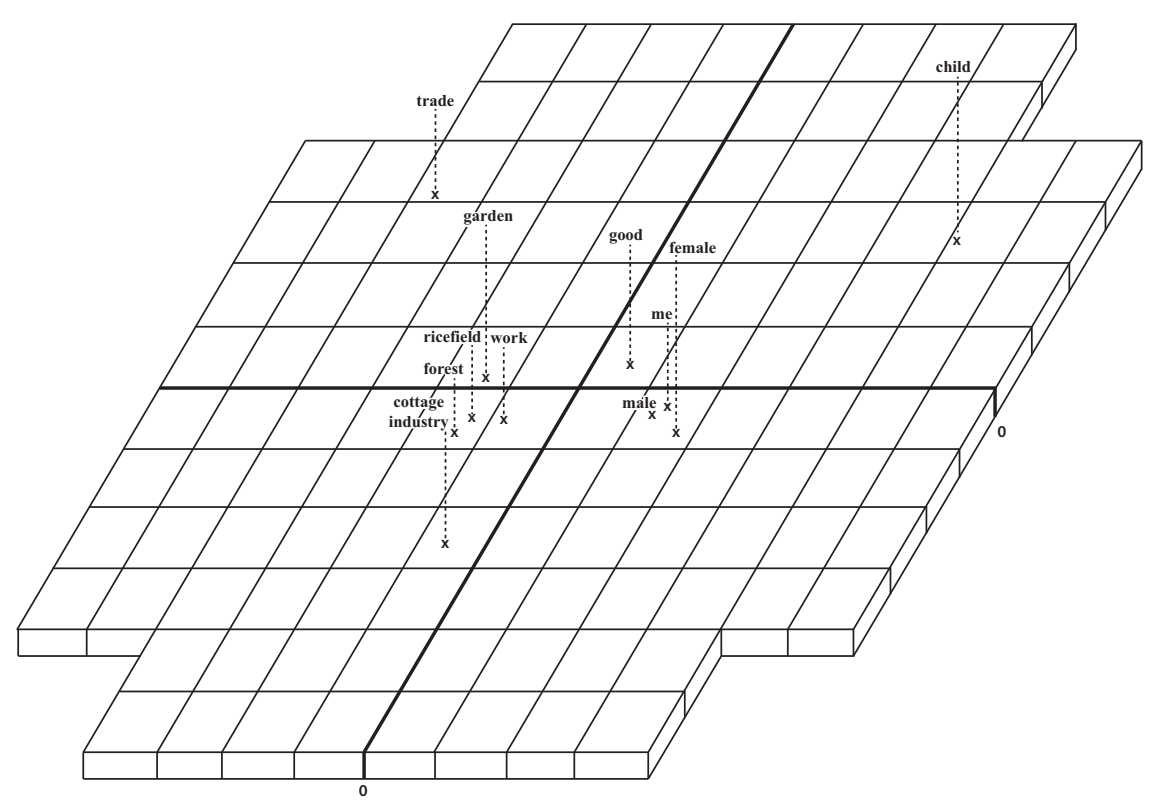

FIGURE 4.2 Map showing cognitive distances between men and women in Long Segar, East Kalimantan, 1980.

Source: C. J. P. Colfer, "Women of the Forest: An Indonesian Example." In Women in Natural Resources: An International Perspective, edited by Stock, Force and Ehrenreich. Moscow, Idaho, 1982. 
TABLE 4.1 Galileo means matrix — cognitive mapping study, Kenyah adults, Long Segar, 1980

\begin{tabular}{|c|c|c|c|c|c|c|c|c|c|c|c|}
\hline Forest & $\begin{array}{l}\text { Forest } \\
0.0\end{array}$ & $\begin{array}{l}\text { Rice } \\
\text { field }\end{array}$ & & & & & & & & & \\
\hline Rice field & 1.5 & 0.0 & Garden & & & & & & & & \\
\hline Garden & 1.7 & 2.2 & 0.0 & Male & & & & & & & \\
\hline Male & 3.0 & 2.6 & 4.0 & 0.0 & Female & & & & & & \\
\hline Female & 3.7 & 2.0 & 1.7 & 2.0 & 0.0 & Child & & & & & \\
\hline Child & 6.4 & 6.1 & 6.0 & 3.2 & 1.2 & 0.0 & Work & & & & \\
\hline Work & 2.4 & 1.4 & 1.4 & 1.5 & 1.4 & 5.7 & 0.0 & $\mathrm{Me}$ & & & \\
\hline $\mathrm{Me}$ & 3.0 & 2.1 & 4.0 & 1.9 & 1.8 & 2.0 & 1.4 & 0.0 & Good & & \\
\hline Good & 2.4 & 1.8 & 2.2 & 2.2 & 1.8 & 2.4 & 1.4 & 3.1 & 0.0 & Trade & \\
\hline Trade & 5.1 & 4.3 & 4.2 & 6.3 & 6.8 & 7.4 & 4.3 & 6.4 & 5.1 & 0.0 & $\begin{array}{l}\text { Cottage } \\
\text { Industry }\end{array}$ \\
\hline $\begin{array}{l}\text { Cottage } \\
\text { Industry }\end{array}$ & 3.1 & 2.6 & 3.7 & 3.2 & 1.4 & 7.0 & 1.2 & 2.7 & 1.9 & 6.4 & 0.0 \\
\hline
\end{tabular}

Source: C. J. P. Colfer, "Women of the Forest: An Indonesian Example." In Women in Natural Resources: An International Perspective, edited by Stock, Force and Ehrenreich. Moscow, Idaho, 1982

Long Segar. The government had in 1975 declared Long Segar a Resettlement Village, providing the people with various 'inputs' (seeds, farming tools, extension services and pressure to plant paddy rice), like the transmigrants discussed in Chapter 5. This change also meant that the community's presence there was acknowledged by the government; formal certificates of land ownership were promised, though not forthcoming. The core of Kenyah subsistence was swidden agroforestry, supplemented by hunting, fishing, gathering and periodic male wage labour, sometimes with the US-based Georgia Pacific timber concession two hours downriver. ${ }^{20}$

Although men and women participated almost equally in swiddening labourthe most common forest-dependent agricultural method in the tropics-in Long Segar (Colfer 1981), ${ }^{21}$ rice production was considered women's profession. Men emphasized other elements of the subsistence system (hunting, fishing, gathering and periodic wage labour). As with many other groups, women were more involved in reproductive activity (child- and eldercare, cooking, cleaning) than men. But the division of labour was flexible. Men could also often be seen washing clothes, cooking and taking care of children. Although men usually piloted canoes, women also took the helm. There was no taboo against women doing what men more typically did or vice versa.

Kenyah seem to be singularly nonjudgmental about either sex performing tasks that are most commonly undertaken by the other. The harsh . . . ribbing that accrues in some places to people who deign to engage in activities reserved by that group for the opposite sex is entirely absent. The Kenyah are aware of sex role rigidity among some other ethnic groups they have 
encountered. Kayan men, for instance, were described to me as responding to floor sweeping in the same way that American men have learned to respond to dishwashing and diaper changing. But the Kenyah merely chuckle about such cultural foibles.

(Colfer 2008, pp. 198-199; also noted by Appell 1991)

The harp portrayed at the beginning of this chapter reflects a common set of harp strings and relevant chords that create the personal songs plucked by Kenyah men. If we turn to the harp's frame, the elements of stability within the system, I see again the three sides: The first, shared with Bushler Bay, but manifested differently, is the ongoing oscillation between competition and cooperation. Whereas in the US, there's an underlying expectation of competitionthat's what's emphasized, especially for men-among the Kenyah, cooperation is expected. Although cooperation is expected and common, the frequency with which men compete will also be clear in the pages that follow.

The second side of the Kenyah harp frame is the distinction between generosity and greed. Social pressure to share is phenomenally strong. ${ }^{22}$ Yet there is recognition that people do behave selfishly. No one is surprised when a local leader cheats and takes more than his share, or when a family hides the meat they've brought home, keeping more for themselves-contrary to the norm of sharing all with their extended family and neighbours. But children are taught very consistently to share what they have, and all agree that's the right thing to do. I did not hear among the Kenyah the idea that there were ethical principles that one had to follow at great risk to one's self. They were eminently practical people.

The last side of the Kenyah harp pertains to the distinction between aristocrats (Paren) and commoners (Panyen) on the one hand, and a value on equality on the other. This distinction has come under attack, both from within and without. I describe later the headman, Pelibut's efforts to obliterate it; he brought both the Christian church and democratic ideals to bear in support of his view. People continued to consider the status of any man (or woman) according to this division, and it affected political, marital and economic decision-making. On the other hand, everything was somehow meant to be divided equally. Each person on a long expedition got an equal share, each person out hunting or fishing or collecting forest products got an equal share. Food in the household was divided into equal portions on all the plates. As with the other two sides of the harp, both concerns had to be taken into account.

\section{Expedition-making as a masculine harp string}

The activity that captured men's fancy and had traditionally taken a great deal of their time was expedition-making. ${ }^{23}$ It was men's equivalent of swiddening for women. Kenyah men's 'harp strings' involved courage and making wondrous journeys; women sought to be hardworking and produce quantities of rice. 
But some women went on journeys and most men participated in the agricultural cycle. Courage and hard work were admired in both men and women; the respective emphasis simply shifted somewhat.

In Long Ampung, sources of trade goods, salt and wage labour had been distant. So groups of men would routinely make long sojourns up over the central mountains of Kalimantan, fording rushing streams and making their way through dense forests to Sarawak, the closest access point for these desired goods. In 1980, men were still bringing back cloth, tools, kerosene, guns, cooking pots, tobacco, sugar, MSG and salt, among other things (Colfer 1985b).

Making such a journey was a dangerous undertaking, which required knowledge of paths through the forest, ways to garner foods from nature and care in protecting the group from dangerous animals or, in earlier times, other headhunters. Such trips were an informal rite of passage for boys, a study of needed knowledge for adult men and a test of leadership for organizers. They were also exciting adventures that many (though not all) men looked forward to and anticipated with both fear and delight. Bonds between men who went on expeditions together remained throughout life, as did memories of their adventures.

I was in Long Ampung in May 1980, when a group of 15 men and one woman $^{24}$ returned from one of these adventures. ${ }^{25}$ They'd been gone a year. The community-excited both to see their menfolk and also the goods they brought back -immediately organized Uman Usen (to 'eat salt'), a ritual party to celebrate their safe return. Salt is essential to human life, and its unavailability locally meant that it was considered the gold of the Apo Kayan ${ }^{26}$ — a key contribution men made to community health. By 1980, salt was more available; there was an airstrip a day's walk away at Long Sungai Barang, with a missionary plane occasionally stopping there. But salt was still in short supply. Bits of salt were given out to each family by the returning men, and salt was tasted as well. The men recounted their adventures, sharing new knowledge acquired in their travels. One time the men had brought back a new kind of pineapple plant that was not as spiny as that available locally. Another trip yielded the knowledge that an empty pressurized container could blow up. I was surprised at the variety of information, some quite esoteric (American kissing contests, trips to the moon), they'd gleaned. Kenyah curiosity and knowledge about the world beyond was impressive, particularly when compared with what I'd observed in rural Turkey in the 1950s, where villagers rarely left home and were more committed to obeying tradition.

\section{BOX 4.1 EXPEDITIONS AMONG THE IBAN-THOSE LEFT BEHIND}

In 1991-1992, I lived in remote Danau Sentarum (interior West Kalimantan) and conducted ethnographic research among the Iban and Melayu living there. ${ }^{27}$ One day the Melayu headman of the village of Pulau Majang took 
me, reluctantly, by motorized canoe through the low brushy flooded forest that covered much of the region, into the beautiful, dense, high, flooded forest near the village of Empaik where I hoped to spend a few nights with the Iban. His anxiety at being in this forest and near these ex-headhunters was palpable-there was a long history of Iban taking Melayu heads more recently than Kenyah involvement in such pursuits. He tried to hide his fears and dropped me at the end of a trail with instructions about how to reach the village.

As I walked along the path, I came to a group of women sitting in a field hut, drinking arak (a strong alcoholic drink) as they took a break from their rice weeding. My appearance struck fear into their hearts-they had never seen a white woman before, and who knew what mischief I might be up to? The bravest of them came and asked me what I was doing, and as I explained that I'd just come to visit them, they gradually relaxed. My agreeing to sing some American songs helped to further dispel their anxiety. Eventually, after warning me that they would kill anyone who stole their husbands, they invited me to sit with them in the field hut and drink some of their arak.

As we chatted, it emerged that they were actually there consoling themselves. Their husbands had just left for an expedition to Malaysia. They expressed their fears that their husbands would find another woman and not return; though they also maintained that they were unconcerned about hidden affairs if they never learned about them. They expressed their sadness at not having their husbands' warm bodies on their sleeping mats (with extra giggles about implied sexual enjoyments) and that they would miss husbandly massages after a hard day's work in the fields. They knew they would be lonely (see Kedit 1991, on Iban circular migration).

Kenyah expedition-making continued, with the move to Long Segar, with important variations: Trips were shorter and now turned toward Indonesia instead of Malaysia. Rather than obtaining trade goods, men now worked for wages or under contract, mostly in forests, and brought back cash, chainsaws or outboard motors (Colfer and Dudley 1993). But the trips' functions as rites of passage, as adventures and as opportunities to develop and display leadership continued. Clever and ambitious Kenyah men became adept at speaking Indonesian and dealing with the many other ethnic groups intent on harvesting the province's wealth, outside investors with more money, power and education. The Kenyah had to learn to manoeuvre within the negative stereotypes (as 'primitive') that outsiders applied to them, but they were also able to make use of other groups' fear of them. The Kenyah headhunting history was known, and the idea that Dayaks had secret magic was also widespread. ${ }^{28}$ Many of my colleagues from other parts of Indonesia openly expressed their fear of this group, whom some believed had tails. Once, in 1990, an Indonesian colleague, a forester, was so 
frightened of Dayaks that he feigned illness to avoid coming on a mandated field trip to Kalimantan (similar fears persisted in March 2019; See Chapter 7).

\section{The leadership and politics harp strings}

In Long Segar, Pelibut, the headman in whose home I lived, provides an interesting case of admired masculinity. The Kenyah change their names several times during their lives; the Pe-in Pelibut's name indicated that he had grandchildren. The libut was an adaptation of the Indonesian word for a thousand (ribu) and referred to his extensive expedition-making. He'd reputedly gone as far as Irian Jaya (now Papua) and had had marvelous exotic experiences throughout his life.

Among the Kenyah, traditionally there had been three social structural differentiations: aristocrats (Paren), commoners (Panyen) and in earlier days, slaves. ${ }^{29}$ The Paren had had various rights vis-à-vis the Panyen. Paren had been able to use symbolic wooden carvings, certain named beads and artistic symbols on their elaborately beaded baby carriers (Whittier 1973) and graves. They had access to the community's labour, the right to lead and more.

Pelibut was born a commoner; he was the only commoner to become headman among all the Uma' Jalan Kenyah communities. He'd recounted to me his struggles to become leader, including being disdained and spat upon year after year in his earlier years. But he was a clever speaker, another admired masculine tone on the harp, and as his oratorical and intellectual abilities overcame community resistance to his leadership, he was able to lead the people first to accept Bungan Malan (a female deity who required adherence to fewer taboos than had the previous belief system), and then Christianity. ${ }^{30} \mathrm{He}$ had also fought for acceptance of democracy, which he'd argued required dropping the ParenPanyen distinction. By 1979, it was locally 'illegal' to mention this distinction, subject to a fine (though its power still held sway). ${ }^{31} \mathrm{He}$ 'd also led the group who initially settled Long Segar. Besides his leadership, expedition-making and oratorical skills, he was expert at the drawing of patterns for beadwork, carving in wood and bone, massage and blacksmithing; he readily admitted that he was no good at rice cultivation (the backbone of the economy and of women's role).

By the time I knew Pelibut, he was solidly ensconced as the leader of the community (Ketua Adat-customary leader), and no one overtly questioned his leadership. He called meetings and people came. When he negotiated contracts with outsiders involving community labour (e.g., to clear the landing strip across the river, to expand the church), people provided that labour. One time someone died the day I was to fly out from the Georgia Pacific Timber Concession to Samarinda. My colleague, Tamen Uyang, seriously disliked Pelibut's firm hold on power and obliquely questioned his right to lead. But in this instance, he told me that we could not go unless Pelibut agreed, as it was against their custom to leave the village when someone had just died. After some discussion, he agreed to ask for such permission. To my surprise, he did 
this in an overtly submissive way, clearly recognizing Pelibut's right to deny us permission.

This submission came about because of Pelibut's position in the community, but also because of his age. Unlike in the US, age among the Kenyah confers respect. Tamen Uyang was young, in his mid-30s; he was an aspiring leader and upwardly mobile. His mother's family was Paren, and his father's Panyen. As his mother had died at an early age, he'd been raised by her sisters, in a Paren household. However, his ambiguous status meant he had to prove himself worthy of a leadership position more strenuously than would have a full Paren.

In a discussion about the categorization of people, a group of men discussed their criteria. If a person always followed, and didn't give his opinion, then the elders didn't call him or ask him. If he agreed no matter what, they also didn't bother to ask his opinion; they were seeking people who could think. With Paren pebeseq (half aristocratic), if their children were not smart, their children reverted to panyen. To alaq ngadan (to 'get a name'; that is, to be publicly admired), a person must njam pisiu ('be able to speak'), and be tigatawai ('good hearted, friendly'). Bek ia mpi tisen neng joo udip, mpi dulu mengin ia madung. "If he doesn't know how to plan about life, people don't call him to sit [among the decision-makers]."

Tamen Uyang did not seek formal political position, claiming he did not wish to spend his time solving community disagreements or discussing community affairs at great length on his veranda. Instead he wanted to and did lead men on the Long Segar version of expeditions - contracting groups to log or clear ${ }^{32}$ forests for money. He drew on his physical strength, linguistic ability and multicultural sophistication (another version of being 'clever at speaking') to negotiate contracts with outsiders. This sophistication was gained during his long and enforced stay in Malaysia during the 'Confrontation' between Indonesia and Malaysia (1963-1966).

Another man, Tamen Balan, had been appointed formal village leader. Tamen Balan was literate, making him an acceptable candidate to the government, and he was Paren, making him more acceptable to the community. However, he was young, mid-30s, which meant he could not comfortably challenge Pelibut, despite the latter's illiteracy. Nor did Tamen Balan exhibit any apparent wish to do so. When I asked why none of the other older Paren men had become leader, I was told that they were not clever at speaking, and thus could not lead effectively. Paren men readily acknowledged this shortcoming in themselves. All feared to debate Pelibut, whose leadership by then went unchallenged.

Relations among men were a bit reminiscent of the relations among loggers in the easy performance of a specified task. Men cooperated without much bossing behaviour; ${ }^{33}$ each knew his (or a useful) part in performing the task. Attitudes toward time differed however. There was no concern about following any schedule; men didn't care how long the task took usually, and there was little interest in making its conduct efficient. 'Time' had not been 'money' traditionally. Nor had there been much interest in productivity. In Long Ampung, where most of the people I knew had grown up, their fields produced enough for the family 
with some to spare; a big surplus was of little advantage. In Long Segar, interest had grown in, and they had success at, producing surplus for sale, but attitudes about time were slow to change.

\section{BOX 4.2 ON GOOD-NATURED KENYAH MEN}

I was standing on the shore admiring the beauty of the Kayan River and the forests and fields beyond, in the comparative cool of late afternoon [in Long Ampung], just having finished my bath. A peaceful moment of pleasure. My attention was drawn to a raft coming around the bend in the river, with several men on it. It quickly became clear that this raft of logs was coming apart and that the men on board were trying to salvage the situation. They called out to those of us on shore, laughingly explaining their predicament. Several men near me jumped into the river, also laughing and working to retrieve the logs that had come free. With considerable effort, all good-humoured, they managed to reassemble the raft and continue down the river.

Images of American men working together kept coming to my mind. In the US, someone in the group would probably have been angry, blaming someone else for tying the logs incorrectly or for ineptitude in handling them or for slowness in retrieving them. The image of these men joyously solving life's problems remains with me, symbolizing the equanimity of the Uma' Jalan [Kenyah] in difficult situations and their ability to turn potential pain into pleasure (Colfer, Peluso, and Chin 1997, p. 7).

In one sense, the community was ruled by the old men. When a community decision had to be taken, the old men assembled on Pelibut's porch and discussed what ought to be done, usually far into the night. Eventually, a consensus (or nearly so) was reached and a decision was made. Anyone-man, woman or child-who wanted to listen and even participate in these discussions could do so, but the final decision-makers were these elderly men.

This same group was responsible for making legal decisions. When adultery occurred, for instance, the couple first tried to resolve it themselves. If that was ineffective, they involved their close family members. Men and women had equal voice in these small groups, influenced by the intelligence and wisdom of the individuals. If the problem was still not resolved, it was brought to these elderly men, who tried to understand what had happened, attribute blame and mete out appropriate punishment, normally a fine. Once the decision had been made and the fine paid, community members were prohibited from referring to it again. Anyone who was heard doing so was him/herself subject to a fine. Fines were typically shared between the victim and these elderly men. Being one of these elders involved more duties and hardships than raw power. 


\section{Courage as a harp string}

Mashman (1993), drawing also on Freeman (1979), writes of the Iban:

The underlying values of bravery (berani), boldness (kempang), and strength (kering) are central to any explanation of Iban aggression, warfare, and headhunting. A man of bravery and strength will have tattoos on his throat, a sign that he has endured pain, and a headhunter will have tattoos on his fingers ... These values are reinforced through myth, ritual, and the daily division of labor.

The interest of Kenyah men in their own bravery has been briefly mentioned, but tattooing was not the avenue by which Kenyah men demonstrated it. It was Long Segar's women, rather than men, who sported tattoos; they were not symbolic of masculinity. Many elderly Kenyah women had a series of tattoos on their finger joints, lower arms and varying portions of their legs. Young women were unlikely to get tattoos even in the 1980s, but by the 1990s, some young men had begun to. At that time, the government was organizing the killing of tattooed men on Java, reportedly because of their assumed links to crime syndicates. This may have prompted a new (or renewed?) link with courage among Dayak men (though this is speculation).

The desire to prove one's courage takes on greater salience when we consider the practice of inserting pins into their penises. When I learned in February 1980 - to my surprise - that many of the men of Long Segar indeed had their penises pierced, I asked why. I received the most common reasons given for their use in Borneo, also described by Brown (1991) and Zahorka (2017): the pleasure of a woman in intercourse and evidence of male courage.

A few prove their courage by climbing the glorious tanyit tree (Koompassia excelsa) - a tree reaching heights of $88 \mathrm{~m}$ (https://en.wikipedia.org/wiki/Koompassia_excelsa). The dramatic and beautiful tanyit, described earlier, was also often selected by bees for their honeycombs. I was told about groups of Kenyah gathering at the base of the tree, singing songs to encourage the bees to leave, while some brave man ventured up its trunk to the towering heights of its crown. Smoke was used to force the bees away, and the honey would be harvested and shared, to everyone's delight. Admiration was expressed for the courage, skill and danger such a harvest entailed.

The value on courage was not, however, absolute. A young man of our household turned over a tractor at work, injuring himself and others. When he came home, he was chastised by the older men for being overly makang (brave, fierce). Basically, he was warned against being foolhardy, told to admit when he didn't know how to do something.

Courage was also used in relation to speech. Pelibut referred once to a man sitting near us as not berani (brave) to take initiative. This man would only do 
what others told him to. The man himself agreed with this assessment. In another example, a man had talked of moving away from the Apo Kayan, a controversial topic, in front of a government official. His fellow villagers asked him why he had the courage to do that. Had the headman told him to? He responded, no, but the community had. I was told of young boys in the Apo Kayan who were makang, enduring the stings of pellets shot from bamboo 'guns' without flinching or running away, even when they drew blood. Tamen Uyang spoke of more physical competition among young men in the Apo Kayan in his youth, compared to the then-current young men. This could, however, have been the ubiquitous tendency to malign the youth of today, whatever the era. A man well known for his singing and composing ability was also admired for his courage: He recited one of his songs/poems (dayong) when the Indonesian soldiers were in Long Ampung during the Confrontation with Malaysia in the mid-1960s. It ended with the rhymed Kenyah phrase 'Jaat ale' se' alo' tantara' ('Very bad looking, the foreign soldiers').

Women could also demonstrate courage however. The women told me that they did not cry out during childbirth. One told how she crossed her arms over her belly to give herself strength during contractions. In a 1980 survey of all the adult women in Long Segar, I asked whether the women spent the night alone at their field huts, typically far from the village - as a measure of marital trust/ jealousy and autonomy. But responses also had a bearing on courage. Although some women expressed fear of killers and spirits as reasons for not spending the night there, 84\% responded yes, when asked if they did so (Colfer 1985a, p. 202). The occasional involvement of women in expeditions was also recognized as courageous (as was my own travel from America to Indonesia). In Long Ampung, 12.5\% of women had made such an expedition. In Long Segar, where 'civilization' is much closer, 50.2\% had travelled (Colfer 1985b, p. 228).

\section{Provisioning as a harp string}

Not all expeditions were to distant places. People, especially men, went on shorter trips to hunt and fish to feed themselves, their families and neighbours. With some persistent wheedling, I persuaded Tamen Uyang to bring me along on a hunting and fishing trip with three other men (Tamen Long, his teenage son Madang and Tamen Uyang's uncle Tamen Kihin). We were heading up the Mela River, which split off from the Telen to the northwest, a few kilometres upriver from Long Segar, in two motorized canoes. Our destination was a densely forested and unpopulated area. The Mela, unlike the lazy, wide, brown Telen, was clear, fast-moving, and full of rapids. The trip upriver was exciting and beautiful, as we passed largely undisturbed areas of forest, interspersed with stretches of limestone cliffs. The further upriver we went, the narrower the river, the more rapids we had to traverse. Many times, we had to get out of the canoes and portage them and our belongings up over rapids to the next clear area.

The abundance of fish we were catching was amazing to me. But my very American excitement and glee were met with some discomfort. My fellow hunters 
told me that they'd believed in the past-and it seemed to me that in fact they still believed - that the fish were presenting themselves to us as a gift, that we should recognize the sacrifice the fish were making and accept it with dignity, gratitude and some solemnity. Their attitudes were protective and caring. I felt ashamed of my greed and thoughtlessness.

The men fished with cast nets - a sight I enjoyed, as these strong men draped the cast nets over their muscular arms and, with great skill and elan, tossed the net, creating a full circle of ripples on the water. Kenyah women did not find this sight of interest. For them, it was perhaps like an American woman seeing a man drive a car. To survive and thrive in the Long Segar environment, most young and middle-aged men were physically strong-or they had to come up with a niche role (discussed later in the chapter). Physical strength was appreciated in men for what they could thereby accomplish, and to that extent was associated with masculinity, but I never heard Kenyah men express any pride or admiration for their own or their friends' muscles per se (unlike the presentday Punan Murung of Central Kalimantan; Grossman 2017). Kenyah pride in physical strength had to do with its utility (including in competition), rather than masculinity per se. Strength and stamina in women were also admired.

Our fishers had accumulated many fish in the canoes by the time we reached a suitable camping area in late afternoon. There, two men began gathering poles to fashion a makeshift hut, complete with a pole floor for us to lie on, while the other two went off with their rifle to hunt. The fact that two men were good at hunting and two at fishing was accepted, with pleasure at the skills available to the group. Tamen Uyang, who had played an important role in fishing (but readily acknowledged his lack of skill at hunting), cooked the rice we had for dinner.

The hunters came back about dusk, and we began the arduous task of converting a deer into meat. Although I tried to be helpful, my lack of skills or knowledge was pitifully obvious. As night bore down on us, I was given the task of holding the flashlight while the men salted the catch. Utterly exhausted from a full day in the hot tropical sun and much physical exercise, I could hardly keep my eyes open. Yet no one suggested I take a rest, no special concern was expressed for me as a woman. I was expected to do my part, even if it was a very minimal, unskilled part.

When we finally were able to lie down, I expressed my fear about snakes possibly getting into my mosquito net. The men assured me they could (and would) take care of any snakes that came along. They expressed their own fear of bali (spirits). There was no shame in expressing such fears. It did not reflect badly on their courage; all Kenyah feared spirits. They considered fear to be logical and sensible in some situations. We made the practical arrangement that I would deal with the bali and they would deal with any snakes we encountered. All were happy with the trade.

The next day, returning to the village, we stopped a few kilometres short of Long Segar. The men took all the meat and fish out of the canoes and spread it on a blue plastic tarp on the river bank. They began dividing the harvest into 
five equal piles, one for each of us. I objected, saying that I had not contributed to the work, that I had been, if anything, a drain on their energies. But this reasoning was not accepted; indeed it prompted a rare expression of anger. The men insisted that I had come along, that even the smallest child who came along on such a trip would get an equal share. People were expected to do what they could (as had been shown the night before when, so exhausted, I was required to hold the flashlight); those who could contribute were expected to, those who couldn't were 'brought along' (ilu ngkin ida). Parents share with their children; children later share with their parents. The men all agreed about this, also making no gender differentiation. The Kenyah were proud that there were 'no Kenyah living under bridges', as some had seen in Java, and they felt that their strong ethic of sharing was an important reason. ${ }^{34}$

Readers may assume that men everywhere are providers. I do not believe that the Kenyah thought of men (any more than women) in that way. They spoke of men as providing money and goods; as contributing to rice cultivation, hunting, fishing and gathering forest products. But with women such a backbone of rice production, ${ }^{35}$ and rice so strongly valued (as shown in the cognitive map in Figure 4.2, for instance), their image was of men and women contributing together to family prosperity and health.

\section{Strength and protection as harp strings}

In general, the denser the forest, the more relevant it was for men's subsistence activities and the more dangerous it was. Men tended to seek out new areas for rice fields each spring, in old growth (mpa'); ${ }^{36}$ men hunted and gathered forest products that flourished in mpa'. The local rationale was that men were stronger, braver and more likely to be able to deal with dangerous animals (and in previous times, other headhunters). But this difference was one of degree. Women also collected forest products, fished, cared for gardens (banit), usually in secondary forest, and often made their way through dense forest to reach their rice fields; they, like the Javanese transmigrant women described by Elmhirst (2018), also valued their own strength.

The difficulties people encountered dealing with forest regrowth prompted me once to ask if people considered forests to be their enemies. Tamen Uyang first replied "yes", but as he considered it, he concluded instead that work was really their enemy, "because it kills us". I asked if people ever waged war (pepatai) against the forest itself. He replied, "Only if two people are fighting to see who's strongest, others might tell them to go fight with the forest and make a big rice field or carry a load of rice, if they want to show how strong they are".

One time, I went on an outing with several middle aged and older men, through old growth forest (mpa') looking for a new area for the next year's rice field. My bush knife, which had been attached to my waist band, had fallen off and I hadn't noticed. Pebilung, a wizened man in his 60s who navigated the forest with amazing agility, told us to wait, that he would retrieve it. I doubted he could 
possibly find it, as we seemed to have been meandering through mpa' without any paths or guideposts. However, in about ten minutes, he returned, knife in hand. I was impressed by and praised Pebilung's agility and speed. All agreed, saying "Pebilung was very strong when he was young-indeed, they said if there were 1000 people, maybe there would be four like Pebilung when he was young . . . He could carry heavy loads and still go fast in the forest".

I made many trips with Tamen Uyang, both to other communities and to the many fields in the Long Segar vicinity. He did not overtly protect me. When we discovered that our canoe was directly under a poisonous snake relaxing on a branch once, he quickly moved the canoe-but that was protecting everyone in the canoe, including himself. He reminded me at night to take a flashlight when I wandered the village, as snakes also came out at night. But when my husband came and joined me there, Tamen Uyang reminded him as well. The women in my household also reminded me to bring my flashlight at night, not to go into the forest alone and to wear a protective sunhat when I left during the day. Men treated me as an equal, and that's also what I saw in most other male-female relations. ${ }^{37}$

There was one situation in which Tamen Uyang expressed dismay and fear relating to my safety. I don't know if this is evidence of male protectiveness of women, human protectiveness of humans or fear of adverse consequences. We were riding in a canoe that he was piloting, and he steered it a little close to the bank. A branch brushed our canoe and I avoided being hit only by brushing it away at the last minute. He was upset about his own handling of the canoe and my potential injury and asked me in a worried voice if my husband would not blame him if I'd been blinded by the twig. Those who harmed others, including unintentionally, tended to be fined. That applied to both men and women.

\section{Headhunting and violence as harp strings}

Headhunting, at least in the American imaginary, is linked to masculinity (Hoskins 1996). Kenyah men had once been headhunters-ending in the 1930s - and I imagined when I first arrived that I would encounter some related propensity for violence among them. ${ }^{38}$ Pelibut was one of two people in the community who had any memory of actual headhunting, and that was when he was very young. In 1980, any propensity for violence seemed directed outward (like headhunting) toward other groups and internal relations were remarkably gentle and kind. I found no rite of passage ostensibly substituting for the role of headhunting in this process, as George (1996) found in Sulawesi.

Though the last head was discarded in 1963, people did talk about their headhunting past, sometimes with embarrassment, remembering wars with adjacent ethnic groups, particularly the Bakung. People reported hunting heads for various reasons: land disputes, fame, women and for religious purposes. Only the chief of the longhouse could hang heads in his rafters. The actual killer got a symbolic head 
to display. Tamen Uyang spoke of his childhood desire to headhunt - his grandfather had been a famous headhunter and community leader-and linked it with courage and strength. Pelibut remembered the excitement when men returned from a headhunting trip. He spoke of the community's earlier worries, when headhunting was forbidden and certain gender-differentiated taboos were abandoned, that men would become like women, a concern reiterated by Tamen Uyang.

Pelibut recounted earlier ideas about sengka (Setaria Palmifolia) — a long slender forest plant that became limp once cooked, which men avoided eating for fear of becoming 'woman-like' (pekua' leto). Some men still avoided sengka. Men also could not eat payau (sambar deer, Cervus unicolor), pelanuk (greater mouse deer, Tragulus napu) or tela'o/uca' (barking deer, Muntiacus muntjac) in times past. But such taboos were no longer observed.

Pelibut claimed to have been one of two men first to reject these ideas, when he accepted the deity, Bungan, a cult he maintained began in Long Ampung, in 1942 (Colfer and Dudley 1993; see also Urano 2010). By the mid-20th century, people still sacrificed pigs to her. They'd burn the hair on the back of the pig's body, the smell of which appealed to her, and they'd ask to be invincible in war and strong, rich and healthy in life. Then they'd kill and eat the pig. Their conversion to Christianity involved still more reduction in taboos.

There were a variety of links between headhunting and the supernatural. Supernatural help was regularly requested, and signs in nature were seen to grant protection to headhunters. One example involved waiting for a particular small bird to fly to the left of or through a circle hung between two trees to indicate that a headhunting outing would go well. Conversely, a hawk flying to the left was a bad sign, whereas flying to the right or in a circular pattern predicted a positive outcome. If the signs were right, people were said to have no fear.

I encountered very few violent incidents during my year-long residence: one, violence against malfeasant young teenagers; another, against a spouse; the third against a wife and child. In the first case, a big commotion out on Pelibut's veranda drew me out, early in my stay there. I saw Pelibut storming around the veranda, ranting and raving in a very threatening manner at two young teenage boys cowering in fear, tied to the support posts in the middle of the veranda. Although I did not as yet understand much Kenyah, others explained that Pelibut was threatening the boys with no food or water, with possible beatings and berating them for their actions. I was genuinely concerned about their welfare and struggled within myself with what I should do. The violence I'd anticipated seemed about to transpire.

It emerged that the boys had stolen a chicken from someone in the neighbouring Kutai community. Relations between the two communities, separated only by a small stream, were tense at the time. Both communities were part of a government resettlement programme, ostensibly sharing governmental inputs equally. But there were questions about the fairness of a recent division of plywood and roofing material. Additionally, the Kenyah were Christian, the Kutai Muslim; the two communities potentially competed for nearby lands for rice cultivation 
(a Kenyah specialty), for beli'en (Eusideroxylon zwageri) for making shingles (a Kutai specialty) and other forest products. Kenyah cows, which wandered free, had recently wrecked some Kutai gardens, raising the level of mutual antagonism (Colfer, Soedjito, and Azier 2008, orig. 1980).

I gradually learned that there was genuine concern among the men (and perhaps the women too) about the potential local political implications of this thievery and a feeling that the punishment had to be public and seen as serious by the Kutai. Little by little, as the day wore on, the boys' parents appeared and contributed additional lecturing and some dramatic posturing along with a few good whacks. Onlookers restrained parents who seemed in danger of injuring the young perpetrators. The ringleaders were singled out for more painful punishment, while the four younger boys, also tied to posts, looked on in fear. Adult men reminded them of their own culpability. Later that day, after additional pokes, prods, unattractive haircuts and further lectures by a policeman and a man from the nearby timber company, the boys were released, without much in the way of harm beyond the experience of fear, very unattractive haircuts and embarrassment. There was definitely more drama than abuse involved in this show, though it probably served as a potent lesson for the youths.

Beyond this, I never actually saw a Kenyah raise a hand to a child. Tsing (1996) concluded about the Meratus in Central Kalimantan that, although she heard a man threaten in public to beat his own child once (in proof of his courage), in fact she found "no evidence at all that child-beating ever occurred". The Kenyah are remarkably patient with their children, putting up with tantrums and other behaviour that few Americans would tolerate. However, the amount of social pressure that both parents and the community at large exert is considerable- on issues like generosity, cleanliness, respect for elders and fair contribution of labour. Expectations are high, but gentle means of enforcement are the norm for both men and women. Lying and thievery, though disapproved, are in fact more acceptable to Kenyah parents.

The second case also occurred early in my tenure there. Again, there was a commotion on the veranda. I found a group of people discussing a case of domestic abuse (Colfer, Peluso, and Chin 1997). One spouse had been beaten, was tired of being subjected to repeated attacks and had brought suit in the traditional way against the aggressor. The 'court' of elderly men had decided that the aggressor should be fined. The discussion at the time I arrived was about how much the fine should be. After some discussion, the men determined the amount of the fine and the division between the victim and the 'court' (as was usual). It was only some time later that I discovered, contrary to my initial assumption, that the victim was the husband, not the wife. Pronouns in neither Kenyah nor Indonesian specify gender. When asked why he hadn't fought back, my friend said, "He didn't like to fight". The woman was definitely seen in this case as the wrongdoer.

As time went on, I looked for further evidence of anything one might call child abuse; only one was uncovered. A man was reported to have attacked his wife and stepson with a beam. Over my years of involvement with this community, I heard of one more case of domestic abuse, by a woman. This woman, 
who attacked her husband with a wooden beam, was pushed to this extremity by his repeated infidelities and related public embarrassment. Violence within the community is not condoned for either sex.

I was told of one case of sexual violence that had occurred many years earlier. A group of young men were reported to have gang raped a girl who was mentally challenged in Long Ampung in the 1950s or 1960s. This was reported with shame and disapproval. And there were stories of inter-ethnic conflicts during the days of headhunting, when Kenyah women were reportedly raped by Bakung invaders. But accounts of this event vary; another version involves Kenyah women out hunting, being helped to carry home their pigs by Bakung men and making love with them of their own free will, thus angering their husbands who went to war with the Bakung. As in Indonesian, the term for force (ase') is far more likely to refer to social pressure or unwanted verbal advances than to physical violence.

\section{Sexuality as harp string}

Everything in this world has male and female.

There can't be man without woman or woman without man.

(Pejalong, a man, an elder, 1980)

First, we want to talk with each other (across the sexes), then we want to touch, then we want to sleep together, then we want to make love. That's true of all human beings, men and women. And if we begin to feel that things are going in that direction, the proper thing to do is to tell your parents or your relatives, or just the people of the community so they can arrange a marriage. Don't just go sleep together.

(Tamen Uyang, a middle-aged man, 1980)

Young boys have a thing [penis] that gets angry [a'un ca inu neng aang ilu ya' keto'] and wants to live [mudip] if it is near girls.

(Pelibut, a man, an elder, 1980)

Attitudes toward heterosexuality initially reminded me of the situation in US high schools in the 1950s. There was mild disapproval of premarital sexuality, greater disapproval of extramarital sexuality, and in both cases, such disapproval was greater for women than for men, though both clearly engaged regularly. There was also an element of secrecy about it. But any such tendencies were strongly reinforced by Christian missionaries, who had a significant impact on local beliefs.

Pelibut, for instance, had married a number of times in Long Ampung before settling down with his final wife. Earlier in his life, marriages had been easily arranged and dissolved without fanfare or disapproval. But the Protestant KINGMI church (a Lutheran offshoot) forbade divorce, whereas interestingly, the local Catholic church did not.

When I first arrived in Long Segar, I had to report to the local Camat (county head), a Javanese man, appointed by the Indonesian government. Discussions with him revealed that he had sexual access to some young Dayak women within his kecamatan (county) — access that was accepted, somewhat reluctantly, by Long 
Segar community members. My sense was that outsiders who engaged sexually with Kenyah women tended to feel that such behaviour was an affront to Kenyah men, a sort of one-ups-manship, but I saw no evidence that Kenyah men saw it that way. Kenyah men did not control women's sexuality, nor were women considered to belong to their husbands or fathers. Women were locally expected to make their own decisions about their sexuality (also noted by Tsing 1993, among the Meratus) - though the community might not be particularly happy about those decisions, some of which resulted in unplanned pregnancy.

Tamen Uyang advised one woman whose husband was involved in an extramarital affair not to leave as the husband would be happy, having a 'standby booking' (his words!) and she'd have a hard time finding another husband, with child in hand. On another occasion he said, "men can close their eyes, and there are lots of women to choose from, but women can't find another man even if they open their eyes wide searching [with appropriate kinesics]". There are also proverbs about this inequity:

1 Ia tusa pelenca urong-lit. it's hard to make a gourd sink. Fig: It's hard for a woman to find a man.

2 Ia kimet ulu re, yare' uben iko' oo'-lit. She thought it was the head but really it was the tail (of the snake). Fig: She thought he was the first in a long string, but really he was the last to ask for her hand.

On the other hand, a joke told about both men and women seeking divorce suggests equality:

While discussing divorce, a couple went to their rice storage hut. The husband went up to get some rice and the wife stood below. She saw her husband's penis and decided against the divorce. They went home and made up.

The same story is told with a man standing below looking up at his wife's vagina, with the same outcome.

Men are usually expected to be the initiators of courtship. As with the Iban, young men would ask (menyat jaboq) and be given permission to sneak into a girl's sleeping mat and lie quietly, snuggling with her. Such affairs were conducted secretly, and were accepted, even expected, with the idea that intercourse was not to take place (though it sometimes did). When my late-adolescent son came for a brief visit, local girls attempted to seduce him, after which local men mildly reprimanded him for acquiescing. Such sleeping together suggests an ongoing relationship.

More powerful Kenyah men locally had easier sexual access to women than did others. Two middle-aged leaders I knew well were involved in multiple extramarital affairs. ${ }^{39}$ When/if they were caught, they were required to pay a fine; if they persisted, they were threatened with expulsion from the community, 
though I did not know of any cases where this actually happened. The fact that husbands and wives shared their incomes meant that in effect the spousal victim was doubly impacted when a fine was levied: by the initial adultery and by losing some of the household's income/assets. Women could also be fined for adultery-most commonly considered among widows or divorcées.

There was no American-style 'war of the sexes'. ${ }^{40}$ Where Americans tell tales of the Amazons fighting against men, the Kenyah tell myths about magical women coming to the rescue of Kenyah heroes (e.g., Awing in the tale of Balan Tempau). ${ }^{41}$ The situation coming closest to such 'warfare' occurred when groups of men and women worked together in rice fields. Young men and women took turns singing; the gist of the singing was cross-sex teasing about who initiated sexual encounters.

Another idea, which could mildly pit men against women relates to ideas about semen. Some men expressed the idea that making love cumulatively reduced men's lifelong supply of semen and ultimately drained their strength. ${ }^{42}$ This served to discourage sexual excesses for some men.

Whereas many American men expressed admiration for a man who makes love with many women, the Kenyah expressed ambivalence. One man was described, with humor and a touch of disapproval, as being salet sait ["strong at fucking"], meaning that he and his wife made frequent, energetic and prolonged love. Indeed, this was mentioned in connection with purported fear that their lovemaking would bring down the field hut (on stilts) where two couples were staying. Another man got angry when his men friends called out publicly that he sait [was fucking] a woman he was not married to, even though he was in fact doing so. He wasn't worried about being fined, but rather the disrespect. The dual purpose of penis piercing has already been mentioned: demonstration of courage and enhancing a woman's sexual pleasure. ${ }^{43}$

Although I did not know of any individuals whose sexual orientation was different enough to remark on, I did have a couple of conversations suggesting that at least the older generation was aware of possibly non-heterosexual alternatives. Pelibut described two men in the Apo Kayan who had done everything like women. They dressed as women, did the work of women, and in get-togethers joined the women. They never married and lived alone. He expressed no rancor or sanction, only amused acceptance. This came up because a visitor's little boy looked like a girl. He had worn skirts for a long time and still (age six) refused to have his hair cut. The boy listened throughout this conversation, in which no disapproval was shown-again, merely amused acceptance. He hid his face in his mother's lap but seemed shy rather than ashamed. I recorded another similar instance, of a five-year-old boy wearing a dress, whose behaviour was commented on, a simple observation without apparent disapproval. ${ }^{44}$

I had been told that whistling was inappropriate for women, but forgot one day:

I apologized for forgetting and whistling and Pelibut, who served in loco parentis, reiterated, "Don't whistle. A woman [who does this] imitates/acts 
like a man" [Ayen nyepeleu, leto pekua' laki]. That's what they tell children. The word kelake' means a woman who does men's work. She cuts wood, makes sirap [shingles] and prahus [canoes]. Kelake' marry and otherwise lead normal lives. He said I was one. But for men, keledo' - men who do women's work - they don't marry or have kids, are afraid of the dark, cook well, like to play with ${ }^{45}$ the youth [pemuda], take care of children and pigs. His adult daughter and the pemuda pemudi [youth] were sitting listening amusedly. They didn't know about this either but thought it was funny. There were two [like this] when they were in the Apo Kayan [Long Ampung].

(notes, Long Segar, 1980)

As with many things, harmless difference is noted. I did not see it as real disapproval at the time. But insofar as it may have been, it is far less extreme than the aversion one saw in those days, and in some places still, in the US or now in parts of Africa.

\section{The arts as harp strings}

I mentioned earlier the prestige options for men who did not excel in physical strength, clever speaking, expedition-making or even bravery. There was an appreciation for the utility of various talents and a willingness to seek out the appropriate niche for any non-conforming man. I'm reminded of one young man who was obviously neither strong nor particularly coordinated. He was not good at sports—-soccer being played every Sunday afternoon. ${ }^{46}$ His family encouraged him to excel at school, to aspire to teach school (as he in fact did), since it was clear that he would not excel at the traditional masculine roles/skills.

Other men, not as obviously deficient in these realms, were also able to excel in different arenas. One man was skilled at playing the sampe' (a guitar-like instrument). He also had an excellent memory for Kenyah traditional myths and stories, able to delight his audiences. One time, at a good-bye party for me, he entertained us all by creating a series of refrains to a song he'd produced that poked friendly fun at my interview questions, which asked over and over about numbers of trees, plants and fields: Koda' kadu'? Koda kadu'? [how many? How many?].

Other men were excellent dancers. They danced, holding a shield, with an elaborate headdress of tall hornbill feathers. They could swirl around, bent low, looking up into or hiding behind imaginary trees, imitating or hunting various animals, seeking out headhunters (ayau) to engage in battle using elaborately carved swords. When dance parties were underway, young girls would typically go and pull men of all ages to their feet, one by one, insisting they dance for the crowd. Although women's dances were different, they too were pulled onto 'centre stage' as often as men. Most people complied, though with varying degrees of reluctance, enthusiasm and skill.

Older men, beyond expedition-making or carrying heavy weights, became skilled at weaving fish traps or splitting rattan or bamboo for use in baskets. 
These skills were appreciated, but old women also spent time making valued handicrafts (weaving baskets, fishnets, mats). Any masculine weighting was muted, if it existed at all.

Another case of an unusual but admired man related to the healing arts. Women had traditionally been the midwives, but this man-who had lost half of one leg in a forest encounter with a wild pig-had somehow demonstrated his ability in this realm, and was unanimously accepted as a skilled birth attendant, helping many women through their births. Some women were helped by their husbands as well.

\section{Dominant masculinities summarized}

As with the men in my own personal life and in Bushler Bay, masculinities in both Denpasar and Long Segar included valued masculine characteristics, interests and norms/roles. But both Indonesian cases stand out in the muted nature of gender differentiation. This muting was much more extreme in Long Segar, summarized here.

\section{Ideology}

The Kenyah (unlike the Balinese) exhibited no gendered ideology, despite being bombarded with that of the Christian church, to some extent the Indonesian government and the negative stereotypes of other outsiders (see e.g., Dove 1999, on planters in Indonesia). The idea that women were inferior or inherently different was absent.

\section{Characteristics}

Men were considered likely to be stronger, more courageous and better at speaking publicly. But many women also exhibited and admired these qualities in themselves.

\section{Interests}

Men were most likely to express interest in travel, adventure, leadership and hunting. Although men were the operators of heavy equipment (for timber companies), they did not express the fascination I saw among American men with such vehicles. Kenyah men's interest (like their interest in the utility of their own physical strength) was linked to the capability of such equipment to reduce community labour rather than to inherently masculine qualities.

\section{Gender roles}

Kenyah gender roles were unusually flexible, with the exception of politics. Though women and youth were free to participate in political discussions if they 
chose, they rarely did so once an issue reached the community level. There, old men took charge. Men of middle and old age dominated in interactions with outsiders as well.

Men tended to make expeditions in search of adventure, money and goods. They tended to pilot canoes and handle chainsaws (due to their greater physical strength). They cut the trees to clear swiddens and they carried extra heavy loads. But women also often piloted canoes, traversed forests, gathered forest products and carried home backpacks full of harvests; and men often washed clothes, took care of children and cooked-some of women's more usual tasks_-as needed.

\section{Kenyah men in forests: conclusions}

The depth of the links between Kenyah men and the forest at that time are difficult to convey. The Kenyah lifeway was dependent on the forest in almost every way. Their rice came from swiddens cut from the forest by Kenyah men; many of their dietary complements (fruits, vegetables, leaves) came from the varying stages of forest regrowth (old swiddens and the primary forest where men felt at ease). Their ways to demonstrate skill and acumen were via hunting and fishing in the rivers, many of which were kept clear by the existence of the surrounding forests. The beautiful handicrafts men made from rattan or bamboo or wood were dependent on the forests which provided the raw materials. Kenyah men's dancing mimicked the animals and activities that characterized their forestbased life. A crucial traditional way to achieve distinction derived from making expeditions into and through the forests. And their ethnic identity was forestbased (see Tsing 1999, on Central Kalimantan, or Elmhirst and Darmastuti 2015, on Lampung, Sumatra, for similar evidence of forest-based ways of life).

Of course, these men also played a crucial role in obliterating the forest, as part of their breadwinning norms. Their excellence at speech granted them access to the wealth and power of outsiders, whether from government or industry. Their physical strength and courage, along with their desire to demonstrate both, contributed to their willingness and capability to clear the land for transmigration projects, or industrial timber and oil palm plantations. Although less adventurous than a journey to Malaysia, travel within Kalimantan on such contract bases made satisfactory substitutes for their traditional expedition-making. It also allowed them to visit their families more often, contribute labour at home when needed, and still 'bring home the bacon'.

To write these words at this time, remembering so well and knowing that this habitat and aspects of this culture are truly gone, pains me. But as I discuss in Chapter 7, the Kenyah are a remarkably adaptable and resilient peopleincluding their gender system. These men, who are able to cry in public without embarrassment (Chapter 6), understand and cry with me; but they are carrying on with the courage, hard work and leadership they value in themselves.

On this journey, we took a side trip here into urban and elite Balinese masculinities, and a fuller stop with a group that anthropologists used to call 'primitive', 
the Kenyah. In the next chapter, we move to two cultures once called 'peasant', the Javanese and the Minangkabau; from a forest-based culture to agriculturallybased systems.

\section{Notes}

1 Gender differentiation has increased in urban Indonesia, along with the strength of Islamic fundamentalism (supported internationally) and the spread of the gender policies and stereotypes that characterized Soeharto's New Order.

2 The material on Bali is drawn from several hundred pages of fieldnotes/journal entries (20 June to 21 August 1979) and from memories, accrued during a study on family planning for my master's in public health from the University of Hawaii.

3 The information on forests is drawn from Whitten, Soeriaatmadja, and Afiff (1996).

4 This gentleness in daily life goes hand in hand with extraordinary violence that occurred there in 1965, violence that was not discussed then in Bali and about which I only slowly learned over the years. A similar conflict struck me between the smooth and gentle social relations among the Kenyah, who were reputed to have been fierce headhunters.

5 Besides his wife and daughter, a varying number of servants, mostly relatives from his village, lived there.

6 Thanks to Rebecca Elmhirst for reminding me of these associations.

7 I subsequently examined this claim in Sitiung, West Sumatra (Chapter 5). The word, paksa, usually translated as 'force', very often also means serious social pressure. Social pressure from the village leader and other officials was very effective among the Javanese who are very comfortable with their hierarchical social system. This was the kind of 'force' applied there.

8 Much as I decry this attitude and welcome its near-disappearance in Indonesia now, I personally benefitted greatly from it. It was instrumental in overcoming my fear of public speaking, such that I learned to share my own points of view much more freely.

9 Though certainly men have serious advantages in terms of voice/control within the household, acceptability of polygyny, rights to children in case of divorce and comparative freedom to engage in extramarital sex.

$10 \mathrm{He}$ may even have been perceived as more qualified, if one recognizes the advantages of having a quantitatively oriented profession (demography). On the other hand, being Australian, he may have suffered from association with the general, local distaste for the Australian surfer world in Bali.

11 Though from an American perspective I was pitifully poor at the time.

12 The material for this section comes from the following: published material (Colfer and Dudley 1993; Colfer, Peluso, and Chin 1997 and Colfer 2008); one year of co-residence with Tamen Uyang, field assistant and ultimately one-time lover and father of my son; six large plastic boxes of fieldnotes from many repeat visits and survey results; my own memory and interpretations; personal journals.

13 This description draws on material in MacKinnon et al. (1996).

14 Korean and Malaysian companies operated adjacent to the Georgia Pacific concession.

15 The fear that people from Java tended to have of Dayaks also contributed to their reluctance to stray far from base camps (see Chapter 7).

16 Ardener (1975) provides numerous examples of the muting of women's voices, but here I refer instead to a more general muting of a whole axis of differentiation, glimpsed initially and less completely in Bali, one that has great salience in other contexts. Interesting in light of Connell's (1995) view: "A culture which does not treat women and men as bearers of polarized character types, at least in principle, does not have a concept of masculinity in the sense of modern European/American culture" (p. 68). Connell also notes the muting of gender differences for one of the Australian environmentalists whose life histories she took (p. 138). In later work, Connell (2005) also argues that "cultural consent, discursive centrality, institutionalization, 
and the marginalization or delegitimation of alternatives are widely documented features of socially dominant masculinities" (p. 846), none of which were evident among the Kenyah.

17 Other relevant analyses of Indonesian groups around that time include, e.g., Dove (1981), Drake (1991), Mashman (1993), Tsing (1990), Colfer et al. (2001); the collection by Ong and Peletz (1995) and others. More recently, similar ideas seem to hold: e.g., Elmhirst, Siscawati, and Colfer (2016), Elmhirst (2011), Haug (2017) and Li (2015).

18 The concepts came from local conversation, in the Kenyah language. From Long Segar's population of about 1000, 49 adults responded to the instrument (see Colfer 1982). Sampling took advantage of naturally occurring groups: 30 men working on a village project; and 19 women, on a church project. A similar study is discussed in Chapter 5.

19 The Kenyah word for this was man inu, which means 'making things'. It referred to making traps, mats, baskets, beaded panels and jewelry, fishing nets and other household items - all of which were typically made for subsistence or local use rather than sale. I only saw men making traps and women making beaded panels and jewelry, but I also never heard the idea that only one gender or the other could make any of these items.

20 What I describe here reflects the situation in the 1970s-1980s. After that time, there was increasing land pressure on Long Segar, due to the arrival of timber plantations, transmigration and now oil palm plantations. These people were by 2016 intimately involved also with oil palm as a commodity (Elmhirst, Siscawati, and Colfer 2016). Chapter 7 provides a 2019 update.

21 In an observational time allocation study conducted in 1979-1980, 30\% of women's time was spent in agriculture, vis-à-vis $26 \%$ of men's (Colfer 1981, p. 81).

22 I remember my attempts to keep a few chocolate bars I'd brought from the city for my own selfish enjoyment, sneaking them under cover of darkness, knowing if found, I'd have to share them all.

23 We find some similar interests from Britain, which

bequeathed its English-speaking colonies narratives in literature that merge conceptions of idealized masculinity with leadership and heroism. Many of these narratives revolved around the concept of the journey and the quest.

(Hall 2011, p. 33)

Whereas leadership and journeys were key, western-style heroism and quests were not emphasized among the Kenyah.

24 Tsing (1993) also talks about some Meratus Dayak women's adventurous spirit.

25 In April 1981, my assistant, Tamen Uyang, returned to Long Ampung for further data collection and found 50 men away on expedition.

26 The Apo Kayan [Kayan Highlands] is the area near the Malaysian border in which Long Ampung is located. The Kayan is a river.

27 As noted by Giesen and Aglionby (2000), "DSNP [now Danau Sentarum National Park] consists of a series of interconnected seasonal lakes (danau), interspersed with swamp forest, peat swamp forest, and dry lowland forest on isolated hills" (p. 5). In 1991, it was 80,000 ha and considered a government Suaka Margasatwa (wildlife reserve). The population of 6500 fisher folk lived in 39 villages in or near the park. Forests were well used for timber and non-timber forest products. See e.g., Colfer et al. (1997, 1999, 2000) or Colfer (2006).

28 Indeed, before I went to the field, I was told by another anthropologist that Margaret Mead had told him that Dayaks had potent magic, that he should be careful of what he drank from their hands. An urban legend?

29 Another differentiation that was important in Long Segar was between Protestants and Catholics. Each group had its own neighbourhood and church, with most Paren associated with the Catholics (who'd come later to Long Segar, beginning in 1972).

30 McKay and Lucero-Prisno (2012) summarize masculine concerns across Southeast Asia, including "ideal male qualities of malakas or strength, embodied in pre-colonial datu chiefs or 'Big Men' who combined bravery, physical strength, intelligence, eloquence and rapport with the spirit world to gain followers" (p. 23, italics in original) 
31 One Paren woman, unhappy with Pelibut's leadership, likened the Paren to the valued ironwood (beli'en, Eusideroxylon zwageri), which was being strangled by the [Panyen] strangler fig (lunok, Ficus spp.).

32 E.g., his subsequent "large contract to clear forest for kelapa sawit [oil palm] with [a British plantation manager], from TAD's plantation at Muara Wahau" (journal, 28 March 1996).

33 Cf. the hierarchical organization displayed in the Bushler Bay basketball games, or the obedience required in many American bureaucracies.

34 The strength of this ethic for both men and women is hard to convey. Any excess was expected to be shared. My ten-year-old daughter brought one Barbie doll with its multitudinous accoutrements with her in the one suitcase she was able to bring, her only material links with home. When I did not insist she share out these items, the disapproval was tangible. Many conflicts and antagonisms within the community derived from this ideal of sharing everything equally.

35 In Mozambique, men's breadwinning also loses significance, though the emphasis on men's sexuality is more extreme than among the Kenyah:

In a country where women represent a major part of the labor force, namely in agriculture, breadwinning responsibilities are almost unimportant for an understanding of symbolic gender differentiation when compared with the key role played by sexuality in reproducing the standards of male dominance.

(Aboim 2009, p. 216)

36 Although much of what I write remains today, there is no old growth left in accessible areas (see Chapter 7).

37 There are two exceptions to this pattern: (1) an individual lacking in intelligence: Such people were treated in a less egalitarian way; and (2) in the public, political world: Although women spoke routinely in small groups and within families, and they could participate in public discussions if they chose, they rarely did so. They believed themselves and were seen by others as not typically 'clever at speaking'.

38 Indeed, my parents expressed fears that my head would wind up on a Kenyah veranda.

39 There were other leaders who appeared to remain faithful to their wives.

40 Appell's (1991) description of the Rungus seems applicable to the Kenyah as well:

Among the Rungus [another Bornean group] there is no evidence that females envy males, or vice versa, and there is no evidence of an underlying layer of aggression or antagonism with respect to the opposite sex as represented in mockery, jokes, overt statements, or the play of children. Boys do not tease girls or belittle female roles, and girls in their play do not tease boys or ridicule any of the male roles. Nor is there any association of aggression in coitus in terms of bodily injury either in cases of fornication, adultery, or marital intercourse.

41 Cf. Nyawalo's (2011) Kenyan [African] tales of womanly betrayal:

The vulnerability of a man's life in the hands of a woman is portrayed . . In the story (of Luanda Magere, 'a fierce and brave warrior' of the past] . . . it is the wife who manages to destroy a man whose strength was legendary among his fellow men.

42 Keeler (2017) refers to such beliefs in South Asia and their absence in Burma (p. 224).

43 See also McKay and Lucero-Prisno III (2012) for a brief discussion of the practice among Filipino seamen of inserting small balls along the penis shaft, reported to be 'something extra' for partners (pp. 28-29).

44 I saw the same acceptance of boys behaving more like girls in 1991 in West Kalimantan, where one teenage Melayu boy regularly wore lipstick for a time. It wasn't even remarked upon. 
45 In Kenyah, 'to play with' (main) can be sexual or not, as in English. I did not think he was implying sexuality here, but he could have been.

46 Very different from the basketball games in Bushler Bay. Whoever wanted to play joined either the youth (demanai) or the fathers (tamen) team; the audience came and went as the spirit moved them. No one seemed to care much who won, nor was adherence to rules emphasized, though expertise in playing was admired. Sports competitions between communities were, however, taken more seriously.

\section{References}

Aboim, Sofia. 2009. "Men between Worlds: Changing Masculinities in Urban Maputo." Men and Masculinities 12 (2):201-224.

Appell, George N. 1991. "Individuation of the Drives of Sex and Aggression in the Linguistic and Behavioral Repertoire of the Rungus." In Female and Male in Borneo: Contributions and Challenges to Gender Studies, edited by Vinson H. Sutlive and G. N. Appell, 57-120. Williamsburg, VA: Borneo Research Council.

Ardener, Shirley, ed. 1975. Perceiving Women. London: Malaby Press.

Brown, Donald E. 1991. "The Penis Pin: An Unsolved Problem in the Relations Between the Sexes in Borneo." In Female and Male in Borneo: Contributions and Challenges to Gender Studies, edited by Vinson H. Sutlive and G. N. Appell, 435-454. Williamsburg, VA: Borneo Research Council.

Colfer, Carol J. Pierce. 1981. "Women, Men and Time in the Forests of East Kalimantan." Borneo Research Bulletin 13 (2):75-84.

Colfer, Carol J. Pierce. 1982. "Women of the Forest: An Indonesia Example (republished as 'Uma' Jalan Perceptions of People and Forest' in Colfer 2008. Longhouse of the Tarsier. pp. 243-263)." In Women in Natural Resources: An International Perspective, edited by M. Stock, J. Force, and D. Ehrenreich, 153-182. Moscow, ID: University of Idaho Press.

Colfer, Carol J. Pierce. 1985a. "Female Status and Action in Two Dayak Communities." In Women in Asia and the Pacific: Toward an East-West Dialogue, edited by M. J. Goodman, 183-214. Honolulu: University of Hawaii Press.

Colfer, Carol J. Pierce. 1985b. "On Circular Migration: From the Distaff Side.” In Labour Circulation and the Labour Process, edited by G. Standing, 219-251. London: Croom Helm.

Colfer, Carol J. Pierce. 2006. Vignettes from a Year in Borneo: Local People and Conservation. Lulu.com.

Colfer, Carol J. Pierce. 2008. The Longhouse of the Tarsier: Changing Landscapes, Gender and Well Being in Borneo. Edited by G. N. Appell and Vinson H. Sutlive. Vol. 10, Borneo Research Council Monograph Series. Phillips, ME: Borneo Research Council, in cooperation with CIFOR and UNESCO.

Colfer, Carol J. Pierce, and Richard G. Dudley. 1993. Shifting Cultivators of Indonesia: Managers or Marauders of the Forest? Rice Production and Forest Use Among the Uma' Jalan of East Kalimantan, Community Forestry Case Study Series 6. Rome: Food and Agriculture Organization of the United Nations.

Colfer, Carol J. Pierce, Nancy Lee Peluso, and See Chung Chin. 1997. Beyond Slash and Burn: Building on Indigenous Management of Borneo's Tropical Rain Forests, Advances in Economic Botany; v. 11. Bronx, NY: New York Botanical Garden.

Colfer, Carol J. Pierce, Herwasono Soedjito, and Albar Azier. 2008 (orig. 1980). "On Resettlement: From the Bottom Up." In The Longhouse of the Tarsier: Changing Landscapes, Gender and Well Being in Borneo, edited by Carol J. Pierce Colfer, 45-62. Phillips, ME: Borneo Research Council, UNESCO, and CIFOR. 
Colfer, Carol J. Pierce, R. L. Wadley, A. Salim, and R. G. Dudley. 2000. “Understanding Patterns of Resource Use and Consumption: A Prelude to Co-management." Borneo Research Bulletin 31:29-88.

Colfer, Carol J. Pierce, R. L. Wadley, and P. Venkateswarlu. 1999. "Understanding Local People's Use of Time: A Precondition for Good Co-management." Environmental Conservation 26:41-52.

Colfer, Carol J. Pierce, R. L. Wadley, J. Woelfel, and E. Harwell. 1997. "From Heartwood to Bark in Indonesia: Gender and Sustainable Forest Management." Women in Natural Resources 18 (4):7-14.

Colfer, Carol J. Pierce, Joe Woelfel, Reed L. Wadley, and Emily Harwell. 2001. "Assessing People's Perceptions of Forests: Research in West Kalimantan, Indonesia." In People Managing Forests: The Links Between Human Well-Being and Forests, edited by Carol J. Pierce Colfer and Yvonne Byron, 135-154. Washington, DC: Resources for the Future.

Connell, Raewyn W. 1995. Masculinity. Berkeley, CA: University of California Press.

Connell, Raewyn W. 2005. "Hegemonic Masculinity: Rethinking the Concept." Gender and Society 19 (6):829-859. https://doi.org/10.1177/0891243205278639.

Directorate General of Forest Utilization. 1989. Report on Field Case Studies of Forest Concessions: Appendix 5 on PT Kiani Lestari, East Kalimantan. Jakarta, Indonesia: Ministry of Forestry, Government of Indonesia and FAO.

Dove, Michael R. 1981. "Subsistence Strategies in Rain Forest Swidden Agriculture: The Kantu' at Tikul Batu." PhD, Anthropology, Stanford University.

Dove, Michael R. 1999. "Representations of the 'Other' by Others: The Ethnographic Challenge Posed by Planters' Views of Peasants in Indonesia.” In Transforming the Indonesian Uplands: Marginality, Power and Production, edited by Tania Murray Li, 203-229. Amsterdam, Netherlands: Harwood Academic Publishers.

Drake, R. A. 1991. "The Cultural Logic of Textile Weaving Practices among the Ibanic People." In Female and Male in Borneo: Contributions and Challenges to Gender Studies, edited by Vinson H. Sutlive, 271-294. Williamsburg, VA: Borneo Research Council.

Elmhirst, Rebecca. 2011. "Migrant Pathways to Resource Access in Lampung's Political Forest: Gender, Citizenship and Creative Conjugality." Geoforum 42:173-183.

Elmhirst, Rebecca. 2018. "Departing from Java to Lampung: Locating Javanese Diasporic Practices in Indonesia's Transmigration Program." In Departing From Java: Javanese Labour, Migration and Diaspora, edited by Rosemarijn Hoefte and Peter Meel. Copenhagen: NIAS Press.

Elmhirst, Rebecca, and Ari Darmastuti. 2015. "Material Feminism and Multi-local Political Ecologies: Rethinking Gender and Nature in Lampung, Indonesia.” In Gendered Entanglements. Revisiting Gender in Rapidly Changing Asia, edited by Ragnhild Lund, Philippe Doneys, and Bernadette Resurreccion, 177-206. Copenhagen, Denmark: NIAS Press.

Elmhirst, Rebecca, Mia Siscawati, and Carol J. Pierce Colfer. 2016. "Revisiting Gender and Forestry in Long Segar, East Kalimantan: Oil Palm and Divided Aspirations." In Gender and Forestry: Climate Change, Tenure, Value Chains, and Emerging Issues, edited by Carol J. Pierce Colfer, Bimbika Sijapati Basnett, and Marléne Elias, 300-317. London: Earthscan/CIFOR.

Geertz, Clifford. 1963. Agricultural Involution: The Processes of Agricultural Change in Indonesia. Berkeley, CA: University of California Press.

George, Kenneth M. 1996. "Lyric, History, and Allegory, or the End of Headhunting Ritual in Upland Sulawesi." In Headhunting and the Social Imagination in Southeast Asia, edited by Janet Hoskins, 50-89. Stanford, CA: Stanford University Press.

Giesen, Wim, and Julia Aglionby. 2000. "Introduction to Danau Sentarum National Park, West Kalimantan, Indonesia.” Borneo Research Bulletin 31:5-28. 
Grossman, Kristina. 2017. "Gaharu King-Family Queen: Material Gendered Political Ecology of the Eaglewood Boom in Kalimantan, Indonesia." The Journal of Peasant Studies 44 (6):1275-1292. https://doi.org/10.1080/03066150.2017.1341408.

Hall, Maurice. 2011. "Negotiating Jamaican Masculinities." In Global Masculinities and Manhood, edited by Ronald L. Jackson II and Murali Balaji, 31-51. Urbana, IL: University of Illinois Press.

Haug, Michaela. 2017. "Men, Women, and Environmental Change in Indonesia: The Gendered Face of Development among the Dayak Benuaq." Austrian Journal of SouthEast Asian Studies 10 (1):29-46.

Hoskins, Janet. 1996. Headhunting and the Social Imagination in Southeast Asia. Stanford, CA: Stanford University Press.

Kedit, Peter M. 1991. “"Meanwhile, Back Home . . .: Bejalai and Their Effects on Iban Men and Women." In Female and Male in Borneo: Contributions and Challenges to Gender Studies, edited by Vinson H. Sutlive and G. N. Appell, 295-316. Williamsburg, VA: Borneo Research Council.

Keeler, Ward. 2017. The Traffic in Hierarchy: Masculinity and Its Others in Buddhist Burma. Honolulu, HI: University of Hawai'i Press.

Li, Tania M. 2015. "Social Impacts of Oil Palm in Indonesia: A Gendered Perspective from West Kalimantan.” CIFOR Occasional Paper 124:51.

MacKinnon, J., and Kathy MacKinnon. 1986. Review of the Protected Area System in the Indo-Malayan Realm. Gland, Switzerland: IUCN.

MacKinnon, Kathy, Gusti Hatta, Hakimah Halim, and Arthus Mangalik. 1996. The Ecology of Kalimantan: Indonesian Borneo. Singapore: PeriPlus Editions.

Mashman, Valerie. 1993. "Warriors and Weavers: A Study of Gender Relations Among the Iban of Sarawak." In Female and Male in Borneo: Contributions and Challenges to Gender studies, edited by Vinson H. Sutlive, 231-270. Shanghai, VA: The Borneo Research Council.

Mashman, Valerie, and Patricia Nayoi. 2015. "The Bidayuh of Sarawak, Gender, Spirituality and Swiddens." In Shifting Cultivation and Environmental Change: Indigenous People, Agriculture and Forest Conservation, edited by Malcolm Cairns, 958-971. London: Earthscan.

McKay, Steven, and Don Eliseo Lucero-Prisno III. 2012. "Masculinities Afloat: Filipino Seafarers and the Situational Performance of Manhood." In Men and Masculinities in Southeast Asia, edited by Michele Ford and Lenore Lyons, 20-37. New York: Routledge.

Newton, Barbara J. 1977. "Perceptions of Sex Roles at the University of Hawaii." Paper presented at the Women in Communication Convention, Honolulu, HI.

Nyawalo, Mich. 2011. "Postcolonial Masculinity and Commodity Culture in Kenya." In Global Masculinities and Manhood, edited by Ronald L. Jackson II and Murali Balaji, 124-140. Urbana, IL: University of Illinois Press.

Ong, Aihwa, and Michael G. Peletz, eds. 1995. Bewitching Women, Pious Men: Gender and Body Politics in Southeast Asia. Berkeley, CA: University of California Press.

Tsing, Anna Lowenhaupt. 1990. "Gender and Performance in Meratus Dispute Settlement." In Power and Difference: Gender in Island Southeast Asia, edited by Jane Monnig Atkinson and Shelly Errington, 95-125. Stanford, CA: Stanford University Press.

Tsing, Anna Lowenhaupt. 1993. In the Realm of the Diamond Queen. Princeton, NJ: Princeton University Press.

Tsing, Anna Lowenhaupt. 1996. "Telling Violence in the Meratus Mountains.” In Headhunting and the Social Imagination in Southeast Asia, edited by Janet Hoskins, 184-215. Stanford, CA: Stanford University Press. 
Tsing, Anna Lowenhaupt. 1999. "Becoming a Tribal Elder, and Other Green Development Fantasies." In Transforming the Indonesian Uplands: Marginality, Power and Production, edited by Tania Li, 159-202. Amsterdam, Netherlands: Harwood Academic Publishers.

Urano, Mariko. 2010. The Limits of Tradition: Peasants and Land Conflicts in Indonesia. Kyoto: Center for Southeast Asian Studies, Kyoto University.

Whitten, Tony, Roehayat Emon Soeriaatmadja, and Suraya A. Afiff. 1996. The Ecology of Java and Bali. Singapore: Periplus Editions.

Whittier, H. L. 1973. "Social Organization and Symbol of Social Differentiation: An Ethnographic Study of the Kenyah Dayak of East Kalimantan (Borneo)." PhD, Anthropology, Michigan State University.

Zahorka, Herwig. 2017. "Punan 'Gita,' Penan Benalui, Punan Aput: From HunterGatherers to Average Citizens: Early and Later Experiences of the Author in East Kalimantan.” Borneo Research Bulletin 48:283-319. 